\title{
A novel membrane-bound Ech [NiFe] hydrogenase in Desulfovibrio gigas
}

\section{Serviços $9^{\circ} \circ$ \\ NCBI}

\author{
Print E-mail Add to Marked List Save to EndNote Web \\ Save to EndNote, RefMan, ProCite more options
}

Author(s): Rodrigues R, Valente FMA, Pereira IAC, Oliveira S, Rodrigues-Pousada C

Source: BIOCHEMICAL AND BIOPHYSICAL RESEARCH COMMUNICATIONS Volume: 306 Issue: 2 Pages: 366-375 Published: JUN 272003

\section{Times Cited: 13 References: 30 暻司Citation Map}

Abstract: In the present study, we report the identification of an operon with six coding regions for a multisubunit membrane-bound [NiFe] hydrogenase in the genome of Desulfovibrio gigas. Sequence analysis of the deduced polypeptides reveals a high similarity to subunits of proteins belonging to the family of Ech hydrogenases. The operon is organised similarly to the operon coding for the Ech hydrogenase from Methanosarcina barkeri, suggesting that both encode very similar hydrogenases. Expression of the operon was detected by Northern blot and RT-PCR analyses, and the presence of the encoded proteins was examined by Western blotting. The possible role of this hydrogenase is discussed, relating it with a potential function in the $\mathrm{H}-2$ cycling as a mechanism for energy conservation in $\mathrm{D}$. gigas. The present study provides therefore valuable insights into the open question of the energy conserving mechanism in D. gigas. (C) 2003 Elsevier Science (USA). All rights reserved.

\section{Document Type: Article}

Language: English

Author Keywords: Desulfovibrio gigas; Ech hydrogenase; H-2 cycling; energy conservation

KeyWords Plus: METHANOSARCINA-BARKERI; SEQUENCE; OPERON; GENES; FRUCTOSOVORANS; BACTERIA; SULFATE; ARCHAEA

Reprint Address: Rodrigues-Pousada, C (reprint author), Univ Nova Lisboa, Inst Tecnol Quim \& Biol, Apartado 127, P-2780901 Oeiras, Portugal

\section{Addresses:}

1. Univ Nova Lisboa, Inst Tecnol Quim \& Biol, P-2780901 Oeiras, Portugal

2. Univ Evora, Dept Biol, Evora, Portugal

Publisher: ACADEMIC PRESS INC ELSEVIER SCIENCE, 525 B ST, STE 1900, SAN DIEGO, CA 921014495 USA 